\title{
Development Axle on Buru Island
}

\author{
Tim Kerja PSP2M Uniqbu
}

\begin{abstract}
This article aims to dissect the thinking related to the development of the village where the design of the development is designed collectively but the implementation is very showing the operational differences. The shaft becomes a crucial object in the settlement of village development problems as we place the village as a center of development. Organizational effectiveness approach as a measuring instrument of the relationship of an organization with its environment includes utilizing human and natural resources for the development of rural communities. The proposed strategy is the mechanism of implementation of development and the establishment of a Village development acceleration team as a solution that can overcome the gap planning and implementation of Village development. Local governments should be able to ensure the implementation of the distribution of processed land to villages and then distributed with the capabilities of each village as well as preparing and implementing new policies and regulations on cooperation between Government, investors, and villages in natural resource management.
\end{abstract}

Keywords: Village, Development, Buru, Shaft, Construction

\section{INTRODUCTION}

As the country's policy changes to the village this is a fresh wind for all of us, the development orientation slowly began to shift from urban development to rural areas. ACT Number 6 year 2014 about the village gives the opportunity to the emergence of resource sharing between village community, investors and local governments[1]. The village by this law has a more robust and flexible position related to authority, development planning and finance. The village now has a space defining the scope of origin and local village scale authority (regulation of the Minister of Villages 1/2015). It is the authority of village planning (RPJM Desa and RKP Desa), which must also be respected by governments, provinces, districts and third parties (corporations, international donor agencies and others.) when they want to do development in Village[2]. For real entrepreneurship and planning to be implemented, the village law has outlined that the village is gaining the allocation of State budget and expenditure in the form of village funds and village funds allocation[3].

Given the idea of the village as a shaft of development in the area, it should not be contrary to the real conditions we have. Buru Regency with a total area of $5,466 \mathrm{~km}^{2}$ and has a number of villages 82 certainly the number is far compared to Namlea which still continues to grow as the capital of Buru Regency. The big plan of giving birth to the surrounding villages will be the economic and social buffer where the potential ownership of natural resources is all scattered outside the district capital. The following question is how the village is used as a development shaft and what strategy can be used to realize the planning[4].

As a development shaft, the village is used as the center of implementation of the implementation of regional development[5], development not merely develop or conduct infrastructure but more than that, the development of circles that occur in all aspects People's lives, economics, social, culture, politics, which take place at the macro level (village) and micro (individual)[6]. The important meaning of development is the progress/improvement, the growth as expressed by the experts above, development is a process of change made through conscious and well-planned efforts.

\section{LITERATURE REVIEW}

In accordance with the established Law number 06 year 2014 about the village which is the amendment to the Law Number 32 year 2004 concerning local government should be encouraged by the decentralization of the administrative affairs of village Administration, to Support the smooth implementation of the main tasks and functions of the village government administration in improving community services[7].

Drukker defines, effectiveness as doing the right job, is being efficiencies as doing the job properly. From both the notion that the Drucker is presented, it is clear the difference between effectiveness and efficiency. Lockwood provides a sense of effectiveness analysis, which is the analysis of the output quality of a standard training[8]. Winardi puts the effectiveness of organizational as a measuring instrument of the relationship of an organization with its environment. While Steer explains, that the actual test stone for good management is the ability to organize and utilize the resources available in the task of achieving and maintaining an effective level of operation[9].

Implementation of Village development, in accordance with regulation of the Minister of Home Affairs No. 114 year 2014 About Village development guidelines, is clearly mentioned in article 1 paragraph 9 that; Village Development is an effort to improve the quality of life and life for the maximum welfare of the village community. He said in the foundation of the village's financial management article 2 verses 1 and 2 mentioned that: Village government to develop Village development planning in accordance with its authority by referring to the planning of district/city development, Village development As referred to in paragraph (1) is implemented by the village government by involving the whole village community with the spirit of mutual assistance[10].

In carrying out the development of the village, the Government is doing development through two directions (doubles); Firstly, with participatory planning in the framework of the development of, by and for the village called "Building villages"; Secondly, 
the technocratic planning involving the powers of the village such as Regency/city, provincial and central government in the framework of the development of rural areas called "Building the village"[11].

Both patterns of development have the same purpose but the patterns and ways that do have differences between them. The village law distinguishes between rural development concepts (building villages) and Village development (building villages).

\section{METHOD}

In this study, researchers used the approach of literature studies. The literature study is a study used to dull information and data with the help of various materials in libraries and the Internet such as documents, books, journals, magazines, historical stories[12]. Meanwhile, according to the literature study experts are theoretical studies, references and other scientific literature related to the culture, values and norms that develop in the social situation studied[13].

The data analysis technique used in this research is a content analysis method. This analysis is used to obtain valid inference and can be researched based on its context[14]. In this analysis will be the process of selecting, comparing, combining and sorting various information and data until found the relevant[15].

\section{RESULT}

In building the area, many major problems faced to be solved regional head. History records, that government policies of the central and local areas since the old order, the new Order, and the reform order do not touch the essence that exists. This is what raises the question of poverty, unemployment, low quality of human resources, infrastructure limitations and false economic growth. Because, society is always a weak party that is treated like a "sick person".

Development is a essence that grows from fulfilling the needs of people's lives[16]. But if it does not touch the subtance of the need then the plant is not more than a ceremonial alone. In a strategic development, it is expected to build on construction with matching strategies and resources.

Buru Regency, which is also one of the areas of national and regional Development Scheme in the province of Maluku, is supposed to dare to try to get out of the old paradigm, which still continues to maintain the development pattern of Infrastructure for regional development[17]. But not just sticking with the pattern, the local government should dare to make the village as a development shaft to reach the independence of the region.

The meaning of building a bupolo state of the village is to make the village as a development shaft to achieve regional independence. Things can then be reduced to development with the approach, namely; Sustainable management of natural resources and environment, structuring the rural area, economic development of rural areas to promote the linkage of the city village, capacity building and mentoring of village government apparatus Implementation of the village law in a systematic and consistent manner.

In general, the concept of the village axis makes a closer relationship between environmental, economic and social elements that means there must be a synchronization to grow a more comprehensive development model[18]. Calculating potential and resources is an absolute thing that must be done to be examined and process on a strategy for achieving the objectives of the development itself. We must see the potential throughout the village in Buru Regency which should be a more innovative model of development mapping[19].

Continuing the village as a development shaft, there are some important things that make the word axle so meaningful; In general, the village is a location with the ownership of potential land, natural resources as well as manpower so as to attract real investments in and growing together with the village community[20]. This is the basis of thinking to then give birth to an investment model between society, village and investor.

\section{Discussion}

Village as we know together, apparently have a lot of ornament for the addition of productivity and produce the name of income, live how the management is set to get maximum results [21]. Surely the village stood on the legality of natural resources according to the geographical boundaries owned and this became the initial footing to discuss the management relationship associated with shareholding[22].

Creating a relationship between local governments, villages and investors is not an easy job, the village is required to be able to provide facilities as well as comfort in investing as well as the local government as the facilitator should also the ability to encourage and facilitate the development of village potentials. If these two parts have been formed then at least become an easy step for investors to invest in the village.

Mapping potential based on local resources in each village located in Buru Regency is the first step that should have been arranged in the framework of the regional development so when to establish the Tripartd relationship, the village has been able to orientated on the field of investment as appropriate for the resources they possess[23]. The Data on every institution that has been in charge of development in the village becomes a strong urge for the resource picture is increasingly interesting to be used as referral invest.

Talk about the relationship between the three elements (local government, Investor, village) then required a regulation that can arrange the three to work with each other, there must be a regulatory element for the Investor to conduct economic efforts and vice versa Local government and village for the problem of profit sharing and land arrangement to be made investment[24]. Regulations 
are made governing the rights and obligations to these three elements in order to later in the execution process does not pose a problem that could later make the final goal of this cooperation is not achieved.

The next question is how to create such a relationship in the framework of the village regulation, and also need to remember usually the regulatory framework is made, after the mapping of potential that means the regulation to be present is to support from Resources are owned[25]. Regulation will regulate the pattern of capital distribution, the framework of cooperation and the basis of the division of Business results and its sustainability, so that the regulation is the basis of both action and joint decision.

There is great hope to build a village and explore natural resources with the local government as well as investors, living how the villagers realize all this as an opportunity to change the life of the better Kea.

When understanding the geography of Buru Regency, is a vast expanse of nature, with all the potential and natural resources contained therein is an endowment for all of us who currently reside in the "Land Bupolo" area that we Love together. What is the problem is how then the potential of land can be distributed to support the development and sustainability of the people's life[26].

In general, the characteristics of the villagers according to James Scott stated that farmers primarily in rural areas would essentially want a paternalistic, peaceful and patron-client relationship that guarantees and social security. Farmers rarely appear to take a risky decision, because farmers will think of safety first. Similarly, the phenomenon of village community in Buru Regency which is more likely due to the local culture so to come out and innovate the harder it feels, the most important thing is to do something that spawned a sense of comfort[27].

The society is patterned and maritime, but not so there is also a mixture between the two where one village has the potential of agriculture and fisheries, and this condition many we encounter in almost every region of Buru regency[28]. Patterns of work that require someone more time spent in the fisheries sector, the optimization of agricultural land is increasingly difficult to realize, but behind it there is a potential human resources that can be directed ie the village youths who If they are limited to fisheries or their access to fishery resources. Thus, the opportunities for the optimization of agricultural lands in coastal areas are increasingly open[29]. Understanding the widespread understanding of land is a surface area of the land that includes all identification marks, both stable and predictable, from the biosphere, atmosphere, land, geology, Hydrology and population of plants and animals, as well as the results of human activities in the past and present, as far as the ID marks are given Murad's influence on land use by today and in the future. Within a wide area, land is the resource acquired raw materials needed to support the sustainability of human life and activities. In the context of resource use land classified into several categories, namely mining, agriculture, grazing and forestry[30]. Distributing unfunctioning land in the village to the youths who want to switch professions as farmers is not something easy, the local government should be careful and wise to design a land distribution pattern when later Agree on the distribution of land to the youth who switched professions. Choosing a land distribution pattern is an objectification of land area that has not been installed with the amount of human resources available[31].

Related to the form of distribution of land utilization, there are several theories regarding the form of distribution of the money. Bintarto mentioned at least three forms of land use in residential area, especially in rural areas namely, Nucleated Agriculture Village Community[32], Line Village Community, Open Country or trade center Community[33]. The most important thing that needs to be followed is how the local government will accommodate the importance of optimizing the land in the village to be managed by the village youth with the orientation of empowerment. Hopefully the interference of local governments to distribute land to the village youth can reap the success to strengthen the village economy as well as local food security.

\section{CONCLUSION}

Local governments guarantee the implementation of the distribution of processed land to villages and then distributed land rights for the youth of the village who switched the profession as a farmer, which means that there is no function of land that is at least as young villagers want to participate and to be actualized with the potential of existing land. In addition, local governments also prepare and implement new policies and regulations on minbai between governments, investors, and villages in natural resource management in order to establish a good development relationship with the function of Land. To foster another attraction, investment programs in rural development with Minbai pattern involve the village and villagers as shareholders must continue to be developed and mediated by the local government of Buru Regency.

Need structured planning to realize and develop production centers, agricultural processing industry and fishery, and tourism destinations in the village. At least almost all coastal villages in Buru Regency have the potential but live how the management pattern is able to boost the lives of local villagers. And also need to develop cooperation between villages, between regions, including the cooperation of BUMDesa management. Another important thing to build the village agribusiness through the development of special banks for agriculture, SMES, and cooperatives and build business facilities/business center in rural areas.

To support the whole need to also developed the information and communication technology community for farmers and fishermen to interact with other economic actors in the production of harvest, sales, distribution, and others to to support the expected investment power.

Planned development should be intended to increase the capacity of village government and the village consultative Agency through Facilitation, training, and mentoring in the planning, implementation and monitoring of village development, 
management Village assets and finances, preparing village maps and setting village boundaries, implementing village structuring and developing village information centres. Overall capacity development refers to the preparation of local resources.

\section{REFERENCES}

[1] M. C. B. Umanailo, "Strategi Bertahan Hidup Petani Padi Gogo di Pulau Buru," J. Ekon. Pertan. dan Agribisnis, vol. 3, no. 1, pp. 50-58, Jan. 2019.

[2] M. C. B. Umanailo, "Consumption Diversification of Local Community," J. AGRISEP Kaji. Masal. Sos. Ekon. Pertan. dan Agribisnis, vol. 18, no. 1, pp. 61-74, Mar. 2019.

[3] L. Rumkel, B. Sam, and M. C. B. Umanailo, "Village Head Partnership, Village Consultative Body and Customary Institution in Village Development," Int. J. Sci. Technol. Res., vol. 8, no. 8, pp. 1058-1063, 2019.

[4] M. C. B. Umanailo, M. Nawawi, and S. Pulhehe, "KONSUMSI MENUJU KONSTRUKSI MASYARAKAT KONSUMTIF," Simulacra, vol. 1, no. 2, pp. 203-211, 2018.

[5] A. Hasan Afandi and M. C. B. Umanailo, "Watudakon Citizens 'Social Conflict on Joker Toll Road Development in 2017 in Kesamben District, Jombang Regency," J. Soc. Sci. Res., vol. Special Is, no. 5, pp. 656-661, 2018.

[6] M. C. B. Umanailo, N. Handayani, A. Masniati, S. H. Makatita, and S. Lisaholit, "The Urbanization and Diversification of Farmland Namlea Village," Int. J. Sci. Technol. Res., vol. 8, no. 8, pp. 1049-1053, 2019.

[7] M. C. B. Umanailo, "Overview of Phenomenological Research," 2019, pp. 1-6.

[8] M. C. B. Umanailo, "Studi pada Masyarakat Desa Waimangit Kabupaten Buru," SOCA, vol. 12, no. 12, pp. 63-74, 2018.

[9] S. Rachman, H. Hamiru, M. C. B. Umanailo, Y. Yulismayanti, and H. Harziko, "Semiotic Analysis of Indigenous Fashion in The Island of Buru," Int. J. Sci. Technol. Res., vol. 8, no. 8, pp. 1515-1519, 2019.

[10] M. C. B. Umanailo, "BUPOLO " Movement. 2019.

[11] S. Yusuf, M. C. B. Umanailo, R. N. Putri, D. Qhuril, M. Ely, and D. Darma, "Village Institution Relations in the Utilization of Village Funds in Namlea District," Int. J. Sci. Technol. Res., vol. 8, no. 8, 2019.

[12] M. C. B. Umanailo, R. Umanailo, R. Bugis, and A. T. Bon, "Empowerment Community in Buru Regency," in Proceedings of the International Conference on Industrial Engineering and Operations Management, 2019, pp. 2070-2075.

[13] M. C. B. Umanailo, MASYARAKAT BURU DALAM PERSPEKTIF KONTEMPORER, vol. 53, no. 9. 2015.

[14] M. C. B. Umanailo, Sosiologi Hukum, 1st ed. Namlea: FAM PUBLISHING, 2016.

[15] M. C. B. Umanailo and T. Yatno, Kajian dan Analisis Sosiologi Dalam Bentuk Kumpulan Essay, Makalah dan Opini. 2015.

[16] M. C. B. Umanailo, "Discourse on the Consumerist Community Consumption," J. Soc. Sci. Res., vol. 5, no. 54, pp. 1181-1186, Apr. 2019.

[17] A. Assagaf et al., "Educational Political Policy," Int. J. Sci. Technol. Res., vol. 8, no. 9, 2019.

[18] M. C. B. Umanailo et al., "Dominance of Economic Capital in Political," in Community Development, Decentralization \& Local Autonomy Politic \& Democracy, Fisip Universitas Brawijaya, 2018, pp. 1-120.

[19] R. I. Umasugi, C. C. Costa, M. Apriyanto, M. C. B. Umanailo, and N. Mufidah, "Dominance of Economic Capital in the Political," Int. J. Sci. Technol. Res., vol. 8, no. 9, 2019.

[20] M. C. B. Umanailo, ILMU SOSIAL BUDAYA DASAR, 1st ed. Namlea: FAM PUBLISHING, 2015.

[21] B. Sam et al., "Female Feminism in the Customary Island of Buru," Int. J. Sci. Technol. Res., vol. 8, no. 8, 2019.

[22] M. C. B. Umanailo, MARGINALISASI BURUH TANI AKIBAT ALIH FUNGSI LAHAN, 1st ed. Namlea: FAM PUBLISHING, 2016.

[23] M. C. B. Umanailo, "Integration of Community Empowerment Models [Pengintegrasian Model Pemberdayaan Masyarakat]," Proceeding Community Dev., vol. 2, p. 268, Mar. 2019.

[24] M. C. B. Umanailo, I. Hamid, M. Nawawi, S. Pulhehe, S. Yusuf, and A. T. Bon, "Utilization of Qualitative Methods in Research Universities," in Proceedings of the International Conference on Industrial Engineering and Operations Management, 2019, pp. $2076-2081$.

[25] M. C. B. Umanailo et al., "Comprehension To Village," 2018, pp. 1-2.

[26] M. C. B. Umanailo, "Overview Phenomenological Research," pp. 1-6.

[27] B. S. Amanto, M. C. B. Umanailo, R. S. Wulandari, T. Taufik, and S. Susiati, "Local Consumption Diversification," Int. J. Sci. Technol. Res., vol. 8, no. 8, 2019.

[28] M. C. B. Umanailo, "Kalesang Dorp in Context De Bouw van Village."

[29] L. J. Buton et al., "The Effect of Nasa Liquid Organic Fertilizer Concentration and Planting Distance to Growth and Production of Beans," Int. J. Sci. Technol. Res., vol. 8, no. 9, 2019.

[30] R. Bugis et al., "Workers in the Namlea Market," Int. J. Sci. Technol. Res., vol. 8, no. 9, 2019.

[31] W. Malmia et al., "Problem-Based Learning as an Effort to Improve Student Learning Outcomes," Int. J. Sci. Technol. Res., vol. 8, no. 9, 2019.

[32] A. L. Wabula, M. Musyawir, A. Irmawati, B. Rebel, D. M. Darajat, and M. C. B. Umanailo, "Maghrib Movement," Int. J. Sci. Technol. Res., vol. 8, no. 9, 2019.

[33] M. C. B. Umanailo et al., "Cybercrime Case as Impact Development of Communication Technology That Troubling Society," Int. J. Sci. Technol. Res., vol. 8, no. 9, 2019. 